\title{
Pengaruh Tarum (Indigofera zollingeriana) dalam Pengencer Semen terhadap Viabilitas dan Tudung Akrosom Utuh Pada Spermatozoa Kambing Peranakan Ettawa
}

\author{
The Effect of Semen Diluent on Tarum Solution (Indigofera zollingeriana) to Intact Viability \\ and Acrosome Integrity of the Ettawa Crossbreed Goat
}

\author{
P. Cahyani, Y. S. Ondho dan D. Samsudewa \\ Jurusan Peternakan, Fakultas Peternakan dan Pertanian, Universitas Diponegoro \\ Jl. Prof. H. Soedarto, S.H. Tembalang Semarang, Indonesia 50275 \\ Corresponding email: pujicahyani29@gmail.com
}

\begin{abstract}
This study was aimed to determine the influence of using tarum solution (Indigofera zollingeriana) in semen diluents for viability and acrosome integrity of the Crossbreed Ettawa goat. The material that used in this study was fresh semen of stud Ettawa goats of 2-4 year old 5 goats with the weight of 74-92 kg. The components of the extender used in this study were semen diluent and tarum solution. The result of the study showed the additions of tarum solution in semen diluent did not influence the viability and acrosome integrity of semen PE goats $(\mathrm{P}>0.05)$. The conclusion of this study was the four treatments tested had the same capability in maintaning viability and acrosome integrity of PE goats spermatozoa.
\end{abstract}

Key words : diluent, tarum, viability, acrosome integrity

\begin{abstract}
ABSTRAK
Penelitian ini bertujuan untuk mengetahui pengaruh penggunaan pengencer tarum (Indigofera zollingeriana) dalam pengencer semen terhadap viabilitas dan tudung akrosom utuh semen kambing Peranakan Ettawa. Materi yang digunakan dalam penelitian ini yaitu semen segar pejantan kambing Peranakan Ettawa (PE) sebanyak 5 ekor yang berumur 2-4 tahun dengan bobot badan 74-92 kg. Komponen Bahan pengencer yang dipergunakan adalah pengencer semen dan larutan tarum. Hasil penelitian menunjukkan bahwa, penambahan larutan tarum dalam pengencer semen tidak mempengaruhi viabilitas dan tudung akrosom utuh semen kambing Peranakan Ettawa $(\mathrm{P}>0,05)$. Kesimpulan dalam penelitian ini adalah empat perlakuan yang diujicobakan memiliki kemampuan yang sama dalam mempertahankan viabilitas dan tudung akrosom utuh spermatozoa kambing Peranakan Ettawa.
\end{abstract}

Kata kunci : pengencer, tarum, viabilitas, tudung akrosom utuh.

\section{PENDAHULUAN}

Teknologi inseminasi buatan (IB) merupakan salah satu usaha yang dapat dilakukan untuk meningkatkan populasi, produktivitas dan mutu genetik kambing. Akan tetapi tingkat keberhasilan IB pada kambing masih rendah karena berbagai faktor, salah satunya adalah rendahnya kualitas semen. Kualitas semen sesudah penampungan akan mengalami penurunan apabila tidak segera diolah dan digunakan, maka dari itu untuk mempertahankan kualitas spermatozoa adalah dengan penambahan bahan pengencer. Syarat bahan pengencer yang baik harus memiliki fungsi sebagai penyedia zat makanan untuk sperma, pelindung akibat pendinginan, memperthankan $\mathrm{pH}$, mengatur keseimbangan osmotik dan menghambat pertumbuhan kuman mikroorganisme pathogen (Rahardhianto et al.,
2012). Pengencer semen merupakan kumpulan bahan-bahan yang digunakan dalam pembuatan pengencer dan berfungsi sebagai penyedia nutrisi sperma, antibakteri, bersifat isotonis dan dapat menjadi buffer. Tanaman tarum (Indigofera zollingeriana) dapat dijadikan bahan tambahan pengencer semen karena selain mudah didapat, tarum mempunyai banyak kandungan nutrisi diantaranya protein, karbohidrat, vitamin dan mineral di mana komponen ini juga ada pada semen dan dibutuhkan oleh spermatozoa.

Viabilitas dan tudung akrosom utuh (TAU) dalam proses pengujian semen cair menjadi hal yang penting untuk diamati, karena pengujian viabilitas berguna untuk menentukan kemampuan spermatozoa dalam bertahan hidup pada lingkungan tertentu, sedangkan pengujian TAU berguna untuk menentukan kemampuan spermatozoa dalam mempertahankan enzim yang ada didalamnya yang berfungsi untuk 
melisis zona pellusida pada proses fertilisasi (Rizal, 2006).

Tujuan dari penelitian ini adalah untuk mengetahui pengaruh penggunaan larutan tarum dalam pengencer semen terhadap viabilitas dan tudung akrosom utuh semen kambing Peranakan Ettawa. Manfaat penelitian ini adalah diharapkan dapat memberikan informasi mengenai ada tidaknya pengaruh larutan tarum dalam pengencer semen terhadap viabilitas dan tudung akrosom utuh spermatozoa kambing Peranakan Ettawa.

\section{METODE PENELITIAN}

Penelitian ini dilakukan pada bulan Maret - April 2019 di Balai Inseminasi Buatan (BIB) Ungaran, Kecamatan Sidomulyo, Kabupaten Semarang, Laboratorium Ilmu Nutrisi dan Pakan dan Laboratorium Genetika, Pemuliaan dan Reproduksi Fakultas Peternakan dan Pertanian Universitas Diponegoro Semarang. Materi yang digunakan dalam penelitian ini yaitu semen segar pejantan kambing Peranakan Ettawa sebanyak 5 ekor yang berumur 2-4 tahun dengan bobot badan 74-92 kg. Penampungan semen dilakukan pada waktu pagi hari dan langsung dilakukan evaluasi kualitas makroskopis dan mikroskopis semen segar. Semen kambing PE yang digunakan sebagai sampel penelitian adalah semen dengan motilitas $\geq 30 \%$ pada evaluasi kualitas semen segar.

\section{Media Pengencer}

Media pengencer yang digunakan dalam penelitian ini berupa pengencer semen dan larutan tarum. Bahan-bahan yang digunakan untuk membuat pengencer semen tersusun dari $\mathrm{NaCl}, \quad \mathrm{KCl}, \quad \mathrm{NaH}_{2} \mathrm{PO}_{4} \mathrm{H}_{2} \mathrm{O}, \quad \mathrm{MgCl}_{2} 6 \mathrm{H}_{2} \mathrm{O}$, $\mathrm{CaCl}_{2} 2 \mathrm{H}_{2} \mathrm{O}, \mathrm{NaHCO}_{3}$, glukosa, asam piruvat, penicillin dan akuabides. Bahan yang digunakan untuk larutan tarum merupakan campuran dari tanaman tarum dan akuabides dengan perbandingan 1:50.

\section{Perlakuan dan Penambahan Pengencer Semen}

Semen dari satu ekor kambing PE kemudian dibagi menjadi 4 tabung kemudian dilakukan pengenceran dengan ditambahkan pengencer sesuai dengan volume pengencer yang ditunjukkan oleh spektrofotometer. Semen diencerkan dengan pengencer yang terdiri dari pengencer semen dan larutan tarum sesuai dengan perlakuan yang digunakan yaitu :
T0 : Tidak ada penambahan tarum pada pengencer semen

T1 : Penambahan tarum dengan dosis $1 \%$ pada pengencer semen

T2 : Penambahan tarum dengan dosis $2 \%$ pada pengencer semen

T3 : Penambahan tarum dengan dosis 3\% pada pengencer semen

Setelah dicampurkan antara semen segar dan larutan pengencer lalu dihomogenkan di dalam tabung reaksi, dan dimasukkan ke media water incubator dengan suhu $37^{\circ} \mathrm{C}$. Selanjutnya dilakukan evaluasi terhadap spermatozoa yang telah diencerkan berupa pengujian mikroskopis yang terdiri dari viabilitas dan tudung akrosom utuh.

\section{Variabel Penelitian}

Viabilitas dievaluasi dengan meneteskan 1 tetes semen ke objek glass kemudian ditutup menggunakan cover glass selanjutnya diamati dengan perbesaran 400 kali setiap 30 menit sekali sampai motilitas $10 \%$ yang dilakukan oleh 3 orang panelis. Semen yang telah diencerkan disimpan dalam water incubator dengan suhu $37^{\circ} \mathrm{C}$ (diasumsikan berada didalam organ kelamin betina). Pengamatan dilakukan dengan melihat jumlah spermatozoa yang bergerak progresif dengan spermatozoa yang tidak bergerak.

Tudung akrosom utuh dievaluasi dengan mencampurkan semen dengan larutan formal saline kedalam tabung appendolf dengan perbandingan $1: 4$, kemudian dibiarkan beberapa saat lalu diteteskan diatas object glass dan ditutup menggunakan cover glass. Sperma yang diamati minimal 10 lapang pandang diacak dengan jumlah minimal 200 sperma menggunakan mikroskop dengan perbesaran 400 kali. Spermatozoa yang memiliki tudung akrosom utuh ditandai dengan adanya tudung akrosom yang berwarna gelap. Perhitungan tudung akrosom utuh dapat dihitung dengan rumus sebagai berikut :

$$
\underset{\begin{array}{c}
\text { Tudung } \\
\text { Utuh }
\end{array}}{\text { Utusom }}=\frac{\begin{array}{c}
\text { Spermatozoa bertudung } \\
\text { akromosom utuh }
\end{array}}{\begin{array}{c}
\text { Spermatozoa yang } \\
\text { diamati }
\end{array}} \times 100 \%
$$

\section{Analisis Data}

Data yang diperoleh akan diolah menggunakan program statistical package for social science (SPSS) versi 16. Analisa yang 
digunakan pada penelitian ini adalah uji Kruskal Wallis dan apabila uji Kruskal Wallis menunjukkan perbedaan signifikan $(\mathrm{P}<0,05)$ maka dilanjutkan dengan Pos Hoc Test menggunakan uji Mann Whitney.

\section{HASIL DAN PEMBAHASAN}

\section{Evaluasi Fisik Semen Segar}

Semen kambing Peranakan Etawa yang telah ditampung dilakukan pemeriksaan makrosopis dam mikroskopis meliputi volume, warna, konsistensi, bau, $\mathrm{pH}$, gerak massa dan konsentrasi tersaji pada Tabel 1. Hasil penelitian menunjukkan bahwa volume semen rata-rata adalah 1,74 $\pm 0,94 \mathrm{ml}$. Volume semen segar yang diejakulasikan dalam kisaran normal, hal tersebut sesuai dengan pendapat Tambing et al. (2000) bahwa volume semen kambing per ejakulasi memiliki rata-rata $1,08 \pm 0,47 \mathrm{ml}$. Warna, konsistensi dan semen yang dihasilkan adalah krem, kental dan khas sprermin. Souhoka et al. (2009) bahwa semen kambing normal yaitu warna krem-putih susu, kental dan memiliki bau spermin dan disertai bau khas seperti bau hewannya. Derajat keasaman $(\mathrm{pH})$ semen yang dihasilkan rata-rata $6,88 \pm 0,11$. Toelihere (1981) bahwa spermatozoa aktif dan memiliki daya tahan lebih lama pada $\mathrm{pH}$ 7.00. Spermatozoa kambing rentan mengalami kematian apabila berada pada kondisi derajat keasaman yang lebih rendah atau lebih tinggi dari kondisi netral.

Tabel 1. Evaluasi semen segar kambing Peranakan Ettawa

\begin{tabular}{|c|c|c|}
\hline Pemeriksaan & $\begin{array}{c}\text { Karakteristik } \\
\text { semen }\end{array}$ & $\begin{array}{c}\text { Rata-rata } \pm \\
\text { Sd }\end{array}$ \\
\hline Makroskopis & $\begin{array}{l}\text { Volume (ml) } \\
\text { Warna } \\
\text { Konsistensi } \\
\text { Bau } \\
\text { pH }\end{array}$ & $\begin{array}{l}1,74 \pm 0,94 \\
\text { Krem } \\
\text { Kental } \\
\text { Khas Spemin } \\
6,88 \pm 0,11\end{array}$ \\
\hline Mikroskopis & $\begin{array}{l}\text { Gerak Massa } \\
\text { (Skore) } \\
\text { Konsentrasi } \\
(\text { Sel/106) }\end{array}$ & $\begin{array}{c}+ \\
2810,8 \pm 916,26\end{array}$ \\
\hline
\end{tabular}

Gerak Massa pada semen kambing yang dihasilkan menunjukkan nilai yang tidak baik (+). Gerak massa memberikan gambaran mengenai daya gerak spermatozoa secara massal. Inonie et al. (2016) bahwa pemeriksaan gerakan massa pada semen dibedakan berdasarkan gelombang tebal atau tipis, gerakan secara masal ke satu arah secara cepat atau lambat bergantung pada konsentrasi spermatozoa hidup. Konsentrasi pada semen kambing yang dihasilkan yaitu $2810,8 \pm 916,26 \times 10^{6}$. Hasil yang diperoleh tidak jauh berbeda dengan penelitian Tambing et al., (2000) dan Souhoka et al., (2009) yang menyatakan bahwa konsentrasi spermatozoa kambing berturut-turut $2,80 \pm 0,44 \times 10^{9}$ dan $4,15 \pm 0,20 \times 10^{9} \mathrm{sel} / \mathrm{ml}$.

\section{Viabilitas}

Viabilitas merupakan kemampuan sel spermatozoa untuk bertahan hidup pada lingkungan dan waktu tertentu (Pramono dan Tagama, 2008). Standarisasi minimal persentase motilitas spermatozoa kambing yang diinkubasi dalam water incubator adalah 10\% (Srianto, 2016). Viabilitas spermatozoa memiliki peranan penting karena digunakan sebagai penilaian kualitas semen yang akan digunakan untuk inseminasi buatan. Hasil analisis statistik menunjukkan bahwa interaksi antarperlakuan tidak berpengaruh nyata $(\mathrm{P}>0.05)$ terhadap viabilitas spermatozoa kambing peranakan ettawa (Tabel 2).

Interaksi pengencer semen dengan penambahan tarum berbagai dosis memberikan pengaruh yang sama terhadap viabilitas spermatozoa kambing PE. Hal ini menandakan bahwa penggunaan pengencer semen dengan penambahan larutan tarum berbagai dosis samasama dapat menyediakan zat-zat nutrisi yang diperlukan spermatozoa sehingga dapat digunakan untuk bergerak kedepan dan mempertahankan daya hidup spermatozoa. Menurut Rahardhianto et al. (2012) bahan pengencer yang baik yaitu memiliki fungsi sebagai penyedia nutrisi untuk spermatozoa, pelindung akibat pendinginan, melindungi akibat perubahan $\mathrm{pH}$, mengatur keseimbangan dan menghambat pertumbuhan mikroorganisme patogen.

Tabel 2. Viabilitas dan tudung akrosom utuh

\begin{tabular}{|c|c|c|c|c|}
\hline \multirow{2}{*}{ Parameter } & \multicolumn{4}{|c|}{ Perlakuan } \\
\hline & T0 & T1 & $\mathrm{T} 2$ & T3 \\
\hline $\begin{array}{l}\text { Viabilitas } \\
\text { (Menit) }\end{array}$ & $336^{\mathrm{ns}}$ & $342^{\mathrm{ns}}$ & $276^{\mathrm{ns}}$ & $306^{\mathrm{ns}}$ \\
\hline $\begin{array}{l}\text { Tudung } \\
\text { Akrosom } \\
\text { Utuh (\%) }\end{array}$ & $42,63^{\text {ns }}$ & $44,90^{\text {ns }}$ & $41,12^{\mathrm{ns}}$ & $44,56^{\mathrm{ns}}$ \\
\hline
\end{tabular}


Berdasarkan Tabel 2. viabilitas spermatozoa kambing PE yang diberi perlakuan T1 paling lama yaitu 342 menit, kemudian viabilitas spermatozoa yang diberi perlakuan T2 paling pendek yaitu 276 menit dibanding spermatozoa perlakuan T0 yaitu 336 menit dan T3 306 menit. Hal ini diduga karena penambahan larutan tarum dengan dosis yang berbeda dalam pengencer semen oleh sel spermatozoa direspon secara seragam dalam mempertahankan kualitas semen dan mempertahankan viabilitas sel spermatozoa. Larutan tarum yang ditambahkan pada dosis $0 \%, 1 \%, 2 \%$ dan $3 \%$ tetap mampu melindungi membran sitoplasma yang ada di bagian kepala spermatozoa sehingga mampu mempertahankan gerakan sitoplasma agar tetap progesif. Effendy et al., (2015) menyatakan bahwa proses metabolisme sel sperma menghasilkan reaksi peroksidatif lipid apabila bereaksi dengan radikal bebas. Peroksidasi lipid dapat mengubah struktur sel spermatozoa serta merusak selubung lipoprotein sehingga menyebabkan mantel pelindung sperma menjadi pecah sehingga berakibat pada kerusakan organel-organel sel spermatozoa. Menurut Tambing et al., (2000) menjelaskan bahwa apabila organel-organel sel sperma rusak, seperti mitokondria maka berakibat pada rantai oksidasi akan terputus dan proses metabolisme menjadi terhambat kemudian sel spermatozoa mati.

Larutan tarum memiliki kandungan antioksidan yang berguna untuk meredam reaksi radikal bebas atau senyawa pengoksidasi dan berperan untuk meminimalkan terjadinya reaksireaksi oksidasi. Herdiawan et al. (2014) menjelaskan bahwa tanaman tarum mengandung zat anti nutrisi antara lain tannin, saponin, alkaloid, flavonoid, carbohydrate glycosides, terpeniod, steroid dan indospicin. Palupi et al. (2014) antioksidan dalam tanaman tarum berupa vitamin A, D, E, K, bahan aktif berupa beta karoten serta kandungan asam amino berupa lisin $1,57 \%$ dan metionin 0,43\%. Margaretta et al. (2011) menjelaskan bahwa antioksidan berperan penting dalam penetralkan radikal bebas atau menangkal reaksi oksidasi akibat radikal bebas yang dapat mengakibatkan kerusakan asam lemak tak jenuh, membran dinding sel, pembuluh darah, basa DNA dan jaringan lipid. Spermatozoa dengan membran plasma yang masih utuh menunjukkan persen hidup tinggi dan viabilitas sperma menjadi meningkat.

\section{Tudung Akrosom Utuh}

Pengamatan tudung akrosom utuh diperlukan untuk menjamin keberhasilan dalam membuahi sel telur. Hal ini disebabkan karena tudung akrosom berfungsi untuk melindungi enzim yang ada didalamnya sehingga proses fertilisasi dapat berjalan dengan baik. Hasil analisis statistik menunjukkan bahwa interaksi antar perlakuan tidak berpengaruh nyata $(\mathrm{P}>0.05)$ terhadap tudung akrosom utuh spermatozoa kambing PE (Tabel 2).

Interaksi pengencer semen dengan penambahan tarum dengan berbagai dosis memberikan pengaruh yang sama terhadap tudung akrosom utuh spermatozoa kambing PE. Hal ini menandakan bahwa penggunaan pengencer semen dengan penambahan larutan tarum berbagai dosis sama-sama dapat bekerja dengan sinergi untuk mempertahankan keutuhan tudung akrosom melalui perlindungan membran sel dari kerusakan. Menurut Effendy et al. (2015) proses metabolisme sel sperma menghasilkan reaksi peroksidatif lipid apabila bereaksi dengan radikal bebas. Peroksidasi lipid dapat mengubah struktur sel sperma serta merusak selubung lipoprotein sehingga menyebabkan mantel pelindung kepala sperma pecah dan berakibat pada rusaknya tudung akrosom utuh spermatozoa.

Larutan tarum memiliki kandungan zat aktif yang berguna untuk meredam reaksi radikal bebas dan berperan untuk meminimalkan terjadinya reaksi-reaksi oksidasi dan kerusakan pada membran plasma. Palupi et al. (2014) antioksidan dalam tanaman tarum berupa vitamin A, D, E, K, bahan aktif berupa beta karoten serta kandungan asam amino berupa lisin 1,57\% dan metionin $0,43 \%$. Tethool et al. (2017) menjelaskan bahwa antioksidan dalam pengencer berguna untuk mempertahankan metabolisme sel serta mengatasi laju kerusakan membran sel akibat peroksidasi lemak. Spermatozoa dengan membran plasma yang masih utuh menunjukkan persen hidup dan viabilitas sperma tinggi menandakan bahwa tudung akrosom dan organel sel didalamnya terlindungi.

Faktor penyebab rendahnya TAU dalam penelitian ini diduga kemungkinan karena faktor fisik akibat pengocokan pada saat proses pencampuran semen dengan medium pengencer, hal ini akan menyebabkan efek buruk terhadap keutuhan tudung akrosom akibat benturan spermatozoa dengan dinding tabung reaksi. Susilowati (2010) menyatakan bahwa kualitas tudung akrosom utuh yang rendah dapat 
disebabkan akibat pengaruh kimiawi dalam medium pengencer serta pengaruh mekanik seperti gesekan dengan partikel pengencer atau dengan dinding tabung. Selain itu, kerusakan tudung akrosom dapat berasal dari abnormalitas primer atau berasal dari kegagalan dalam proses spermatogenesis berupa aparati golgi dari spermatid yang tidak membentuk tudung akrosom.

\section{KESIMPULAN}

Berdasarkan hasil penelitian dapat disimpulkan bahwa penambahan larutan tarum dalam pengencer semen tidak mempengaruhi viabilitas dan tudung akrosom utuh semen kambing Peranakan Ettawa. Empat perlakuan yang diujicobakan memiliki kemampuan yang sama dalam mempertahankan viabilitas dan tudung akrosom utuh spermatozoa. Perlu adanya penelitian lebih lanjut tentang penambahan tarum pada pengencer semen antara dosis $0 \%$ dan $1 \%$ sehingga dapat melihat efisiensi dosis yang dibutuhkan dalam pengencer semen.

\section{DAFTAR PUSTAKA}

Effendy, F. I., S. Wahjuningsih dan M. N. Ihsan. 2015. Pengaruh pengencer tris aminomethane kuning telur yang disuplementasi sari kulit manggis (Garcinia mangostana) terhadap kualitas semen sapi limousin selama penyimpanan suhu dingin $5^{\circ} \mathrm{C}$. Jurnal Ilmu Ilmu Peternakan 25 (3): 69 - 79.

Herdiawan I., Abdullah L. dan Sopandi D. 2014. Status nutrisi hijauan Indigofera zollingeriana pada berbagai taraf perlakuan stres kekeringan dan interval pemangkasan. Jurnal Ilmu Ternak dan Veteriner 19 (2): 91-103.

Inonie, R. L., Baa, L.O., Saili.T. 2016. Kualitas Spermatozoa Kambing Boerawa dan Kambing Kacang pada Penggunaan Tris Kuning Telur yang Berbeda. Jurnal Ilmu dan Teknologi Tropis 3 (1): 53-64.
Margaretta. S., S. Dewi Handayani, N.Indraswati dan H. Hindarso. 2011. Ekstraksi senyawa Phenolic pandanus amaryllifolius roxb. Sebagai antioksidan alami. Widya Teknik 10 (1): 21-30.

Palupi, R., L. Abdullah, D. A. Astuti, dan Sumiati. 2014. Potensi dan pemanfaatan tepung pucuk Indigofera $s p$. sebagai bahan pakan substitusi bungkil kedelai dalam ransum ayam petelur. Jurnal Ilmu Ternak dan Veteriner 19 (3): 210-219.

Pramono, E. dan T. R. Tagama. 2008. Pengaruh penambahan adenosin Triphosphat ke dalam Pengencer Semen Terhadap Kualias Spermatozoa Domba Ekor Gemuk. Animal Production 10 (3): 151-156 .

Rahardhianto A., N. Abdulgani, dan N. Trisyani. 2012. Pengaruh konsentrasi larutan madu dalam nacl fisiologis terhadap viabilitas dan motilitas spermatozoa ikan patin (Pangasius pangasius) selama masa penyimpanan. Jurnal Sains dan Seni 1 (1): $58-63$.

Rizal M. 2006. Pengaruh penambahan laktosa di dalam pengencer Tris terhadap kualitas semen cair domba Garut. Jurnal Pengembangan Peternakan Tropis 31 (1): 224-231.

Souhoka D. F., M. J. Matatula., W. Marlene Mesang-Nalley dan M. Rizal. 2009. Laktosa Mempertahankan Daya Hidup Spermatozoa Kambing Peranakan Etawah yang Dipreservasi dengan Plasma Semen Domba Priangan. Jurnal Veteriner 10 (3):135142.

Srianto, P. 2016. Uji mutu semen beku kambing Peranakan Ettawa (PE) dalam tiga macam pengencer yang berbeda dengan pemeriksaan water 
incubator. Jurnal Veterinaria Medika 6 (2): $157-160$.

Susilowati, S. 2010. Efek waktu sentrifugasi terhadap motilitas, daya hidup dan tudung akrosom spermatozoa kambing. Jurnal Veterinaria Medika 3 (1): 61-64.

Tambing. S. N., M. R. Toelihere, T. L. Yusuf dan I. K.Sutama. 2000. Pengaruh gliserol dalam pengencer tris terhadap kualitas semen beku kambing Peranakan Etawah. Jurnal Ilmu Ternak dan Veteriner 5 (2): 1-8.
Tethool, A. N., A. R. Ollong dan J. F. Koibur. 2017. Kualitas mikroskopik spermatozoa ayam kampung (gallus gallus) setelah pemberian sari buah merah (Pandanus conoideus lam). Prosiding Seminar Nasional Peternakan Optimalisasi Sumberdaya Lokal Peternakan Rakyat dalam Mendukung Program Peternakan Berkelanjutan.18 September 2017. Makassar. 77-84.

Toelihere, M. R. 1981. Fisiologi Reproduksi pada Ternak. Penerbit Angkasa, Bandung. 